\title{
Biological activities of the fermentation extract of the endophytic fungus Alternaria alternata isolated from Coffea arabica $\mathrm{L}$.
}

\author{
Maurette dos Reis Vieira Fernandes ${ }^{1}$, Tales Alexandre Costa e Silva ${ }^{1}$, Ludwig Heinrich Pfenning ${ }^{2}$, \\ Cláudio Miguel da Costa-Neto ${ }^{3}$, Tassiela Andréa Heinrich ${ }^{3}$, Severino Matias de Alencar ${ }^{4}$, \\ Marisa Aparecida de Lima ${ }^{1}$, Masaharu Ikegaki ${ }^{1 *}$
}

\begin{abstract}
${ }^{1}$ Universidade Federal de Alfenas / Unifal-MG, Departamento de Farmácia, ${ }^{2}$ Universidade Federal de Lavras, Departamento de Fitopatologia, ${ }^{3}$ Universidade de São Paulo, Faculdade de Medicina de Ribeirão Preto, Departamento de Bioquimica e Imunologia, ${ }^{4}$ Escola Superior de Agricultura “Luiz de Queiroz”/USP, Departamento de Agroindústria, Alimentos e Nutrição, Piracicaba-SP
\end{abstract}

\begin{abstract}
A total of 22 endophytic fungi isolated from coffee (Coffea arabica L.) were cultivated in vitro and their crude extracts tested. The screening was carried out using the agar diffusion method against Staphylococcus aureus, Escherichia coli and Candida albicans. The most effective isolate was Alternaria alternata, and subsequently, its extract was assayed. The total phenolic content was $3.44 \mu \mathrm{g} \mathrm{GAE} / \mathrm{mg}$ of the crude extract. For the antibacterial and antifungal activity assays, minimum inhibitory concentrations (MIC) and minimum bactericidal and fungicidal concentrations (MBC and MFC) were determined. The ranges of MIC values were $50-100 \mu \mathrm{g} / \mathrm{mL}$ for $S$. aureus and $400-800 \mu \mathrm{g} / \mathrm{mL}$ for $E$. coli. The extract did not show activity in the tested concentrations for $C$. albicans. The fungal crude extract was assayed for antioxidant activities. Its ability to scavenge DPPH radicals and antioxidant activity by $\beta$-carotene/ linoleic acid system oxidation was not significant. In addition, antitumor activity was studied using the MTT assay. At a dilution of $400 \mu \mathrm{g} / \mathrm{mL}$, the extract displayed a cytotoxic activity of approximately $50 \%$ towards HeLa cells in vitro. The results indicate that endophytic fungi could be a promising source of bioactive compounds and warrant further study.
\end{abstract}

Uniterms: Endophytic fungi. Bioactive compounds. Alternaria alternata/extract/antioxidant activity.

Total de 22 fungos endofíticos isolados de café (Coffea arabica L.) foi cultivado in vitro e seus extratos testados. A triagem foi conduzida pelo método de difusão em agar contra bactérias Gram-positiva, Gram-negativa e uma levedura. O isolado mais efetivo foi Alternaria alternata e, subsequentemente, seu extrato foi analisado. O conteúdo de fenólicos totais do extrato bruto foi de 3,44 $\mu \mathrm{g}$ EAG/mg de extrato. Para os testes de atividade antimicrobiana, a concentração inibitória mínima (CIM) e concentração bactericida e fungicida mínima (CBM e CFM) contra Staphylococcus aureus, Escherichia coli e Candida albicans foram determinadas. Resultados da CIM variaram entre 50-100 $\mu \mathrm{g} / \mathrm{mL}$ para $S$. aureus e 400$800 \mu \mathrm{g} / \mathrm{mL}$ para $E$. coli. O extrato bruto não apresentou atividade nas concentrações testadas para $C$. albicans. Foram analisadas as atividades antioxidantes do extrato bruto. Sua habilidade para seqüestrar radicais DPPH e a atividade antioxidante pela oxidação do sistema $\beta$-caroteno/ácido linoléico não foram significativas. Além disso, a atividade antitumoral foi estudada pelo teste do MTT. À diluição de $400 \mu \mathrm{g} / \mathrm{mL}$, o extrato apresentou atividade de aproximadamente $50 \%$ sobre as células HeLa in vitro. Os resultados indicam que fungos endófitos poderiam ser uma fonte promissora de compostos bioativos necessitando de estudos futuros.

Unitermos: Fungos endofíticos. Compostos bioativos. Alternaria alternata/extrato/atividade antioxidante.

\footnotetext{
*Correspondence: Masaharu Ikegaki. Universidade Federal de Alfenas, UnifalMG, Rua Gabriel Monteiro da Silva, 700 - Centro, 37130-000 Alfenas - MG, Tel: (0xx35) 3299-1102.E-mail address: masaharu.ikegaki@unifal-mg.edu.br.
} 


\section{INTRODUCTION}

Natural products play a dominant role in the discovery of leads for the development of drugs in the treatment of human diseases. Much of nature remains to be explored, particularly marine and microbial environments (Newman, Cragg, Snader, 2003). Microorganisms have the ability to utilize various substrates as a consequence of the diversity of their biological and biochemical evolution. The solid substrates they use include, among others, live plants. Both bacteria and fungi are known to collaborate with many plants to form mutually beneficial associations. Actinomycetes and fungi, of all microorganisms studied, have been found to be the most prolific producers of secondary metabolites (Guanatilaka, 2006).

In 1990 the magnitude of fungal diversity was estimated at 1.5 million species (Hawksworth, 1991). However, Arnold et al. (2000) suggested that tropical fungal endophytes might prove to be hyperdiverse, and therefore the 1.5 million figure underestimates fungal biodiversity.

In the last few years, considerable knowledge has been accumulated on the biology of endophytic microorganisms (Firáková; Sturdíková; Múcková, 2007).

Petrini et al. (1992) has expanded the definition of endophytes to include all those microorganisms that, during a more or less long period of life, asymptomatically colonize the living internal tissue of their hosts.

Metabolites produced by endophytes are being recognized as a versatile arsenal of antimicrobial agents. Some endophytes have been known to possess superior biosynthetic capabilities, owing to their presumable gene recombination with the host, while residing and reproducing inside the healthy plant tissues (Li et al., 2005). A high proportion of endophytic fungi $(80 \%)$ produce biologically active compounds in tests for antibacterial, fungicidal and herbicidal activities (Schulz et al., 2002). The continued development of new antimicrobial compounds is important to overcome the difficulties related to the treatment of infections caused by resistant pathogens in accordance with Petersen et al. (2004). Thus, endophytic fungi have emerged as an alternative source for the production of new antimicrobial agents.

Due to the importance of secondary metabolite production by endophytic fungi, the study of these coffee fungi provides greater understanding of its diversity.

The purpose of this study was to evaluate several isolated fungi from the Coffea arabica L. plant and to select an endophytic fungus for further evaluation of its antimicrobial, antioxidant and cytotoxic activities.

\section{MATERIALS AND METHODS}

\section{Isolation of the endophytic fungi}

For isolation of the endophytic fungi, adult and healthy leaves of Coffea arabica were selected and subjected to surface sterilization. They were first washed with running water and then immersed in aqueous ethanol (3:7) for 1 minute, then in $3 \%$ aqueous sodium hypochlorite solution for 4 minutes and, finally, in aqueous ethanol (0.2:9.8) for 0.5 minute, with further drying in sterilized paper in a biosafety chamber (Petrini et al., 1982).

The sterilized leaves were cut into $5 \mathrm{~mm}$ diameter pieces and placed in a Petri dish containing $2 \%$ maltextract agar ( $2 \%$ MEA) augmented with $50 \mu \mathrm{g} / \mathrm{mL}$ of chloramphenicol and $10 \mu \mathrm{g} / \mathrm{mL}$ of cyclosporin A, with approximately 5 leaves cut in the shape of a disc on each dish. The material was incubated at $25^{\circ} \mathrm{C}$ for 10 days. All strains were isolated by the culture in 2\% MEA without antibiotic. The fungi were identified by Dr. Ludwig $\mathrm{H}$. Pfenning and deposited in the fungal collection with the accession number Coleção Micológica de Lavras (CML) at the Universidade Federal de Lavras (UFLA).

\section{Fermentation}

For initial screenings, the mycelium of different endophytes grown on $2 \%$ MEA plates were inoculated into $250 \mathrm{~mL}$ erlenmeyer flasks containing $10 \mathrm{~g}$ of wheat bran as the substrate, which was moistened with $10 \mathrm{~mL}$ of distilled water to get an initial moisture content of $100 \%$ before autoclaving at $121{ }^{\circ} \mathrm{C}$ for 20 minutes. These flasks were incubated at $25^{\circ} \mathrm{C}$ for 10 days and the biomass of each endophyte was extracted two times with dichloromethane $(100 \mathrm{~mL})$ at room temperature and further concentrated using a vacuum pump to give crude extracts prior to biological assays. For the production of crude extract on a large scale, the mycelium of the selected fungus was inoculated into $1000 \mathrm{~mL}$ Erlenmeyer flasks containing $100 \mathrm{~g}$ of wheat bran as the substrate with $100 \mathrm{~mL}$ of distilled water to get an initial moisture content of $100 \%$ before autoclaving at $121{ }^{\circ} \mathrm{C}$ for 20 minutes. These flasks were incubated at $25^{\circ} \mathrm{C}$ for 10 days. The biomass of endophyte was extracted and concentrated under the same conditions.

\section{Determination of total phenolic content}

The phenolic compounds of both the crude extract and wheat bran were determined by using the Folin-Ciocateau reagent solution (Woisky, Salatino, 1998). Briefly, the appropriate dilutions of the sample $(0.5 \mathrm{~mL})$ were 
oxidized with $2.5 \mathrm{~mL}$ Folin-Ciocateau reagent (1:10) for 3-8 minutes at room temperature. Then the reaction was neutralized with $4 \%$ saturated sodium carbonate. The absorbance of the resulting blue color was measured at $740 \mathrm{~nm}$ after incubation for 2 hours at room temperature in darkness. Gallic acid was employed as the standard. All tests were carried out in triplicate and the results were expressed as Gallic Acid Equivalents ( $\mu \mathrm{g}$ GAE/mg of dry weight of the crude extract).

\section{Test microorganisms}

The microorganisms used in this study were Staphylococcus aureus ATCC 6538, Escherichia coli ATCC 25922 and yeast Candida albicans ATCC 69548. The cultures were stored at $4-8^{\circ} \mathrm{C}$ in brain heart infusion agar (BHI agar). These microorganisms were kindly donated by the Microbiology Laboratory of the Universidade Federal de Alfenas (Unifal-MG).

\section{Antimicrobial screening}

The $500 \mu \mathrm{g} / \mathrm{mL}$ of each crude extract were screened for their antimicrobial activity using the agar diffusion method (Lorian, 1996). The microorganisms were seeded using the pour plate method. All test plates were incubated at $37{ }^{\circ} \mathrm{C}$ for 24 hours for bacteria and at $25^{\circ} \mathrm{C}$ for $24-48$ hours for yeast. The inhibition zones were observed, measured and recorded. The procedure was repeated and confirmed. The culture of the endophytic fungus Alternaria alternata afforded the most promising antibacterial and antifungal activities and, subsequently, its extract was assayed.

\section{Microbiological assay}

The antimicrobial activity of the crude extract of Alternaria alternata was assayed against bacteria and yeast. A test solution was prepared with the known weight of the crude extract, dissolved in dimethyl sulfoxide (DMSO). The minimum inhibitory concentration (MIC), minimum bactericidal concentration (MBC) and fungicidal concentration (MFC) were determined in accordance with Clinical and Laboratory Standards Institute (CLSI) guidelines (2005) and Duarte et al. (2003), with a few modifications.

Individual colonies isolated from 24 hours cultures of bacteria and yeast were suspended in a sterile $0.89 \%$ $\mathrm{NaCl}$ solution. The suspension was properly inoculated in Nutrient broth for bacteria and Sabouraud broth for yeast, containing a twofold dilution series of the crude extract (concentrations ranged from 50 to $800 \mu \mathrm{g} / \mathrm{mL}$ reaction) to achieve an assay concentration of $10^{5} \mathrm{CFU} / \mathrm{mL}$ or the control DMSO. The tubes were incubated at $37^{\circ} \mathrm{C}$ for 24 hours for bacteria, and $25^{\circ} \mathrm{C}$ for 24 hours for yeast. The test was performed on three replicates for each concentration of the extract. The lowest concentration of extract that had restricted growth to a level of absorbance $<0.05$ at $660 \mathrm{~nm}$ (no visible growth) was recorded as the MIC. To determine the $\mathrm{MBC}$, an aliquot $(50 \mu \mathrm{L})$ of all incubated tubes with concentrations higher than the MIC was subcultured on Nutrient agar for bacteria and Sabouraud agar for yeast. The MBC was defined as the lowest concentration of the extract that allowed no visible growth on the agar plate after the period of incubation (Koo et al., 2000). Three replicates were made for each concentration of the extract.

\section{Antioxidant assay}

\section{Reagents}

All the chemicals and reagents used in this study were of analytical grade. 1,1- diphenyl-2-picryl-hydrazyl radical (DPPH), butylated hydroxytoluene (BHT), ascorbic acid, gallic acid (GA), Folin-Ciocateau reagent solution, sodium carbonate, $\alpha$ - tocopherol, $\beta$-carotene, linoleic acid and Tween 40 were purchased from Sigma-Aldrich, Merck or Vetec.

\section{Free radical-scavenging activity measurement}

Four $\mathrm{mL}$ of dilutions of crude extract and wheat bran $(100,500$ and $1000 \mu \mathrm{g} / \mathrm{mL})$ were added to $1 \mathrm{~mL}$ of $0.5 \mathrm{mM}$ DPPH in $96 \%$ ethanol. The mixtures were vigorously shaken and left to stand at room temperature for 30 minutes in the dark (Yen; Chang; Duh, 2005, with few modifications). Absorbance at $517 \mathrm{~nm}$ was measured versus ethanol as the blank. Standard samples (BHT and ascorbic acid) were used in the same concentrations. A degradation of DPPH was evaluated by comparison with a control $(4 \mathrm{~mL}$ ethanol and $1 \mathrm{~mL}$ of DPPH solution). The DPPH radicalscavenging capacity was calculated by the formula:

$$
\% \mathrm{CS}=\frac{\text { A negative control }- \text { A sample }}{\text { A negative control }} \times 100
$$

Negative control: $4.0 \mathrm{~mL}$ ethanol and $1.0 \mathrm{~mL}$ of DPPH solution. Where $\mathrm{A}=$ Absorbance

$\% \mathrm{CS}=\%$ scavenging capacity

\section{Antioxidant activity on linoleic acid oxidation}

This assay was performed as described by Ahn et al. (2004) with some modifications. $\beta$-carotene $(10 \mathrm{mg})$ was dissolved in $100 \mathrm{~mL}$ of chloroform. Then, an aliquot $(3 \mathrm{~mL})$ of $\beta$-carotene-chloroform solution was added to 
$40 \mathrm{mg}$ of linoleic acid and $400 \mathrm{mg}$ of Tween 40 . Chloroform was then removed under a stream of nitrogen gas. Distilled water $(100 \mathrm{~mL})$ was added, and the solution was mixed well. Aliquots ( $3 \mathrm{~mL}$ ) of the $\beta$-carotene/linoleic acid emulsion were mixed with $50 \mu \mathrm{L}$ of crude extract solution and incubated in a water bath at $50{ }^{\circ} \mathrm{C}$. Oxidation of the emulsion was monitored spectrometrically by measuring absorbance at $470 \mathrm{~nm}$ over a 120 minutes period, in intervals of 20 minutes. The control sample contained $50 \mu \mathrm{L}$ of solvent in place of the extract. The antioxidant activity was expressed as a percentage of inhibition relative to the control after 120 minutes of incubation using the equation:

$\mathrm{AA}=\frac{\mathrm{DR}_{\mathrm{C}}-\mathrm{DR}_{\mathrm{S}}}{\mathrm{DR}_{\mathrm{C}}} \times 100$

Where $\mathrm{AA}=$ antioxidant activity

$\mathrm{DR}_{\mathrm{C}}$ is the degradation rate of the control $\left(=\mathrm{A}_{\mathrm{C} 0}-\right.$ $\left.\mathrm{A}_{\mathrm{C} 120}\right) ; \mathrm{A}_{\mathrm{C} 0}$ is the initial absorbance at time 0 , and $\mathrm{A}_{\mathrm{C} 120}$ is the absorbance at 120 minutes.

$\mathrm{DR}_{\mathrm{S}}$ is the degradation rate in the presence of the sample $\left(=\mathrm{A}_{\mathrm{S} 0}-\mathrm{A}_{\mathrm{S} 120}\right) ; \mathrm{A}_{\mathrm{S} 0}$ is the initial absorbance at time 0 , and $\mathrm{A}_{\mathrm{S} 120}$ is the absorbance at 120 minutes.

The crude extract and wheat bran samples were evaluated at concentrations of 500 and $1,000 \mu \mathrm{g} / \mathrm{mL}$, and $\alpha$ - tocopherol and BHT $(200 \mu \mathrm{g} / \mathrm{mL})$ were used as positive controls.

\section{Cytotoxic assay}

\section{Cell culture and cytotoxic activity}

The Human Cervix Cancer (HeLa) cells were cultured at $37^{\circ} \mathrm{C}$ in a humidified atmosphere containing 5 $\%$ of $\mathrm{CO}_{2}$, using a Dulbelcco's modified Eagle's medium (DMEM) supplemented with $10 \%$ of fetal calf serum (FCS) at $\mathrm{pH} 7.4$. Gentamicin $(10 \mu \mathrm{g} / \mathrm{mL})$ was used as an antibiotic. Cell culture reagents were purchased from Invitrogen (Gaithersburg, MD) and 3-(4,5-dimethylthiazol2-yl)-2,5-diphenyltetrazolium salt (MTT) from Sigma.

On the first day, cells were detached and seeded in a 48 -well plate $\left(2 \times 10^{4}\right.$ cells/well). After 24 hours the medium was exchanged. Solution of the crude extract and wheat bran extract were prepared in DMSO (vehicle). The final concentrations $(400,300$ and $200 \mu \mathrm{g} / \mathrm{mL})$ were achieved by direct dilution into the cell medium. The samples or the vehicle were added and incubated for a period of 48 hours. After this interval, $50 \mu \mathrm{L}$ of a MTT solution $(5 \mathrm{mg} / \mathrm{mL}$ in PBS) were added to each well and the cells were incubated for an additional 3 hours (Mosmann, 1983). Subsequently, the medium was removed, cells were washed two times with PBS, and $300 \mu \mathrm{L}$ of isopropanol-HCL $(0.04 \mathrm{~mol} / \mathrm{L})$ were added. Cell viability was determined by absorbance measurements at $570 \mathrm{~nm}$.

\section{Statistical analysis}

All of the data were expressed as a mean \pm s.d. from at least three separate experiments, each performed in triplicate. The ANOVA test for unpaired observation between controls and experimental samples and Tukey's test for multiple comparisons were conducted to evaluate statistical differences; $p$ values of 0.05 or less were considered statistically significant.

\section{RESULTS AND DISCUSSION}

\section{Isolation of endophytic fungi}

Twenty-two strains of endophytic fungi were isolated and identified from coffee leaves (Coffea arabica L.), as listed in Table I.

TABLE I - Endophytic fungi isolated from coffee (Coffea arabica L.)

\begin{tabular}{|c|c|}
\hline Code & Identification \\
\hline CML 370 & Colletotrichum gloeosporioides \\
\hline CML 450 & Hypoxilan sp. \\
\hline CML 451 & Phomopsis sp. \\
\hline CML 452 & Pestalotiopsis sp. \\
\hline CML 453 & Phoma herbarum \\
\hline CML 455 & Cladosporium cladosporioides \\
\hline CML 456 & Xylaria sp. \\
\hline CML 457 & Colletotrichum crassipes \\
\hline CML 706 & Phoma exigua var. exigua \\
\hline CML 865 & Pseudohalonectria lutea \\
\hline CML 866 & Staninwardia sp. \\
\hline CML 867 & Alternaria alternata \\
\hline CML 868 & Periconia sp. \\
\hline CML 869 & Paracyclothyrium sp. \\
\hline CML 870 & Libertella sp. \\
\hline CML 871 & Phomopsis stipata \\
\hline CML 872 & Myrothecium roridum \\
\hline CML 873 & Microascus sp. \\
\hline CML 874 & Leptosphaeria sp. \\
\hline CML 875 & Microsphaeropsis sp. \\
\hline CML 876 & Microsphaeropsis sp. \\
\hline CML 877 & Guignardia sp. \\
\hline
\end{tabular}

Sette et al. (2006) isolated and identified 37 endophytic filamentous fungi from coffee plants (Coffea arabica and Coffea robusta), which were studied with 
respect to the production of antimicrobial compounds against human pathogenic bacteria. The results revealed that 36 of the endophytic filamentous fungi isolates belong to the Ascomycetes group, including 14 different genera: Aspergillus, Bipolaris, Cladosporium, Clonostachys, Colletotrichum, Epicoccum, Fusarium, Guignardia, Mycosphaerella, Phomopsis, Rosellinia, Talaromyces, Trichoderma and Xylaria.

According to Santamaria and Bayman (2005), who studied endophytic and epiphytic fungal communities associated with coffee leaves (Coffea arabica) in Puerto Rico, Colletotrichum, Xylaria and Guignardia are the most common types of endophytes.

\section{Antimicrobial screening}

The screening was conducted using the agar diffusion method against Gram-positive and Gram-negative bacteria and yeast. All of the crude extracts of fungi isolates inhibited at least one of the microorganisms studied. Among the tested extracts, the Alternaria alternata extract inhibited the growth of three tested pathogenic microorganisms presenting an inhibition zone with diameters measuring between $16 \mathrm{~mm}$ for C. albicans and $27 \mathrm{~mm}$ for $S$. aureus. The other extracts displayed significantly smaller inhibition zones when compared to Alternaria alternata. For this reason, this fungus was chosen for further study.

The crude extract of Alternaria alternata was assessed for several bioactivities such as antimicrobial, antioxidant, and cytotoxic activities.

Table II shows the proportion between isolated fungi extracts and the extracts showing activity against the tested microorganisms.

TABLE II - Antimicrobial activity of extracts from fungal fermentation and fungi isolated from Coffea arabica host plants

\begin{tabular}{lccc}
\hline & \multicolumn{3}{c}{ Microorganisms } \\
& $\mathrm{Sa}$ & $\mathrm{Ec}$ & $\mathrm{Ca}$ \\
\hline Active extracts/total & $18 / 22$ & $13 / 22$ & $8 / 22$ \\
extracts tested (\%) & $(81.8)$ & $(59.1)$ & $(36.4)$ \\
\hline
\end{tabular}

Sa: Staphylococcus aureus; Ec: Escherichia coli; Ca: Candida albicans.

Species of Alternaria are common and prevalent in the mycoflora, which infests and often parasitizes seeds of a wide variety of food crops (Schroeder, Cole, 1977).

The results obtained in this screening showed that endophytic fungi are a promising source of bioactive natural products.

\section{Antimicrobial assay}

The crude extract of Alternaria alternata was assessed for antimicrobial activity against $S$. aureus, E. coli and $C$. albicans. The MIC, MBC and MFC values of crude extract of Alternaria alternata are shown in Table III.

TABLE III - The minimum inhibitory concentration (MIC), minimum bactericidal and fungicidal concentration (MBC and MFC) of crude extract of Alternaria alternata

\begin{tabular}{lccc}
\hline & \multicolumn{3}{c}{ Microorganisms } \\
& $\begin{array}{c}\text { Staphylococcus } \\
\text { aureus } \\
\text { MIC }^{\text {a } \mathrm{MBC}^{\mathrm{a}}}\end{array}$ & $\begin{array}{c}\text { Escherichia } \\
\text { coli } \\
\text { MIC MBC }\end{array}$ & $\begin{array}{c}\text { Candida } \\
\text { albicans } \\
\text { MIC MFC }\end{array}$ \\
\hline $\begin{array}{l}\text { Alternaria } \\
\text { alternata } \text { crude } \\
\text { extract }\end{array}$ & $50-100>800$ & $400-800>800$ & $>800>800$ \\
$\begin{array}{l}\text { Wheat bran } \\
\text { crude extract }^{\mathrm{b}}\end{array}$ & $* *$ & $* *$ & $* *$ \\
DMSO & $* *$ & $* *$ & $* *$ \\
\hline
\end{tabular}

${ }^{a}$ The MIC, MBC and MFC values are expressed in $\mu \mathrm{g} / \mathrm{mL}$. The concentrations of crude extracts ranged from 50 to $800 \mu \mathrm{g} / \mathrm{mL}$. ${ }^{b}$ Three replicates were made for each concentration of the extracts for all assays.

* showed no activity.

The crude extract of Alternaria alternata was the most effective against $S$. aureus, presenting a higher inhibition level when compared to other tested microorganisms.

The structural differences presented in the cellular walls of different types of bacteria and fungi (Tortora, Funke, Case, 2005) are likely to affect the performance of the crude extract. This may explain why the performance of the extract was poorer in the yeast and in the Gramnegative bacterium.

According to Rios and Recio (2005), in the search for substances of natural origin with antimicrobial activity, those that present concentrations higher than $1 \mathrm{mg} / \mathrm{mL}$ for extracts or $0.1 \mathrm{mg} / \mathrm{mL}$ for isolated compounds should be avoided. However, the evaluation of activity is very interesting in the case of concentrations below $100 \mu \mathrm{g} / \mathrm{mL}$ for extracts and $10 \mu \mathrm{g} / \mathrm{mL}$ for isolated compounds.

Compounds isolated from endophytic fungi also displayed antimicrobial activity. Altersin, a natural product isolated from two endophytic Alternaria species, showed a potent minimum inhibitory concentration against several pathogenic Gram-positive bacteria (Hellwig et al., 2002), suggesting that this compound could be present in the crude extract of the fermentation of Alternaria alternata, which requires confirmation. 
In accordance with Lin et al. (2007), in the study of the medicinal plant Camptotheca acuminata, 174 endophytic fungi were isolated. Of the 18 taxa obtained, Alternaria $(12.6 \%)$ was dominant, among others. Of the 22 Alternaria extracts tested, three showed antimicrobial activity.

Of the 67 endophytic fungi isolated from Quercus variabilis, $19.4 \%$ (Aspergillus sp., Penicillium sp. and Alternaria sp.) showed significant antimicrobial activity (Wang et al., 2007).

Phongpaichit et al. (2006) isolated 377 fungi and their fermentation broths were tested for antimicrobial activity. The results revealed that the strains of $S$. aureus (MIC 32-512 $\mu \mathrm{g} / \mathrm{mL}$ ) and C. albicans (MIC 64-200 $\mu \mathrm{g}$ / $\mathrm{mL}$ ) were inhibited by $6-10 \%$ and $1 \%$ of the crude ethyl acetate extracts, respectively.

Thirty-seven endophytic filamentous fungi isolated from coffee plants (Coffea arabica and Coffea robusta) were tested with respect to their production of antimicrobial compounds against human pathogenic bacteria such as Salmonella choleraesuis, Staphylococcus aureus, Pseudomonas aeruginosa and four different Escherichia coli serotypes. Seventeen fungi inhibited at least one of the bacteria studied (Sette et al., 2006).

\section{Antioxidant assay}

The crude extract of fungus Alternaria alternata was evaluated for its ability to scavenge DPPH radicals and antioxidant activity using the $\beta$-carotene/linoleic acid system oxidation. The results are shown in Figure 1 and Figure 2, respectively.

The radical DPPH scavenging activity model is a classic, simple and rapid method of assessing antioxidant activity (Gülçin, Alici, Cesur, 2005). The extracts and the standards, butylated hydroxytoluene (BHT) and ascorbic acid, were assessed at a concentration of $100-1,000 \mu \mathrm{g} / \mathrm{mL}$.

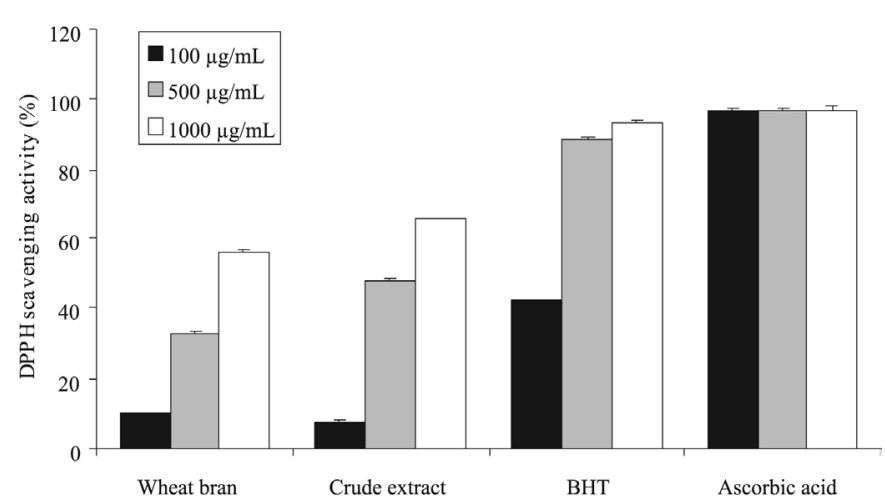

FIGURE 1 - DPPH scavenging activity of BHT, ascorbic acid, and the crude extracts from Alternaria alternata and wheat bran at different concentrations.
At a concentration of $100 \mu \mathrm{g} / \mathrm{mL}$, the crude extract of the endophyte was less significant $(p<0.05)$ than the crude extract of wheat bran. At concentrations of 500 and $1,000 \mu \mathrm{g} / \mathrm{mL}$, a significant difference between the sequestering capability of DPPH radicals by the crude extracts of fungus and wheat bran indicates the presence of antioxidant compounds in the crude extract of Alternaria alternata. This extract presented a sequestering potential of approximately eight times less than the standard BHT, with $\mathrm{IC}_{50}$ of 86.7 and $687.2 \mu \mathrm{g} / \mathrm{mL}$, respectively. The $\mathrm{IC}_{50}$ values were obtained from the plot of absorbance against concentration for each sample. The $\mathrm{IC}_{50}$ is the sample concentration that gives $50 \%$ scavenging capacity.

In the $\beta$-carotene-linoleic acid assay, the linoleic acid free radical attacked the highly unsaturated $\beta$-carotene models. The presence of different antioxidants can hinder the extent of $\beta$-carotene bleaching by neutralizing the linoleate radicals formed in the system (Shon, Kim, Sung, 2003).

The negative control, ethanol, showed the ineffectiveness of the vehicle used in the inhibition of the oxidation of the system, observed by the reduction of the inhibition rate (Figure 2). The standards effectively showed, over time, the ability to maintain the values of inhibition at 120 minutes at $84.7 \pm 1.9$ and $90.7 \pm 2.2 \%$.

The crude extract of Alternaria alternata presented a dose-dependent response. There was no significant difference between the activity of the crude extract of Alternaria alternata at $500 \mu \mathrm{g} / \mathrm{mL}$ and the crude extract of wheat bran at 500 and $1,000 \mu \mathrm{g} / \mathrm{mL}(\mathrm{p}>0.05)$. At $1,000 \mu \mathrm{g} / \mathrm{mL}$, the endophytic extract presented an inhibition rate $(56.4 \pm 3.9 \%, \mathrm{p}<0.001)$ significant to that of the

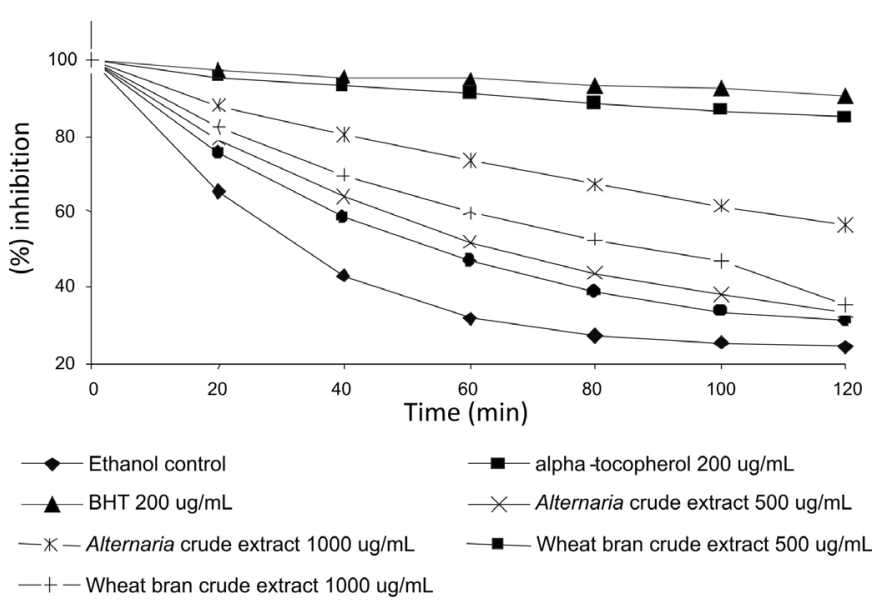

FIGURE 2 - Inhibition rate of oxidation of $\beta$-carotene-linoleic acid system by Alternaria alternata crude extract at different concentrations in comparison with the wheat bran crude extract and the standards. 
crude extract of wheat bran in the same concentration, showing that the performance of the crude extract of Alternaria alternata is independent of the performance of the wheat bran.

The data reinforce the fact that the substrate used in the fermentation process interfered significantly with the determination of antioxidant activity, as this substrate already possessed this ability. According to Soares (2002), the wheat bran extract was described as an important antioxidant agent due to the presence of considerable quantities of phenolic acids, such as protocatechuic, gentisic, caffeic, vanilic, chlorogenic and pherulic acids.

Phenolic compounds seem to have an important role in stabilizing lipid oxidation and are associated with antioxidant activity, which is emphasized in several reports (Yanishlieva-Maslarova, 2001). Therefore, in this study, we determined the total phenolic content of the crude extract of Alternaria alternata and wheat bran, obtaining values of 16.90 and $13.47 \mu \mathrm{g}$ GAE/mg of dry crude extract, respectively.

The difference of phenolic content, which was 3.44 $\mu \mathrm{g}$ GAE/mg of dry crude extract, can be related to the major activity of the endophyte crude extract with respect to the wheat bran extract in the different models of antioxidant activity. However, the content of total phenolics depends on the solvent used in the extraction. In the study of different extracts of endophyte Xylaria sp, Liu et al. (2007) proved that extracts obtained from more polar solvents present a higher amount of total phenolics. In our study, the crude extract of Alternaria alternata, obtained through the extraction with dichloromethane, presented a lower amount of total phenolics, as did the chloroformic extract of Xylaria sp. (12.66 $\pm 0.92 \mu \mathrm{g} \mathrm{GAE} / \mathrm{mg}$ of dry weight of the fruiting bodies) described by Liu et al. (2007). The analysis of 292 endophytes isolated from 29 traditional Chinese medicinal plants showed that the antioxidant capacities of endophytic fungal cultures were significantly correlated with their total phenolic content (Huang et al., 2007). This relationship was also observed in the present study.

In accordance with Silva et al. (2006), a comparison of both antioxidant and antimicrobial activities in relation to the amount of total phenolics of different natural extracts certified that a moderate correlation exists between the amount of total phenolics and the biological activity. In this context, the crude extract of the endophyte Alternaria alternata presented a moderate antioxidant activity in the tested concentrations and, overall, a greater antimicrobial activity, in spite of displaying a lower total phenolic content.

\section{Cytotoxic assay}

The results of the cytotoxic activity of the crude extract of Alternaria alternata are shown in Figure 3.

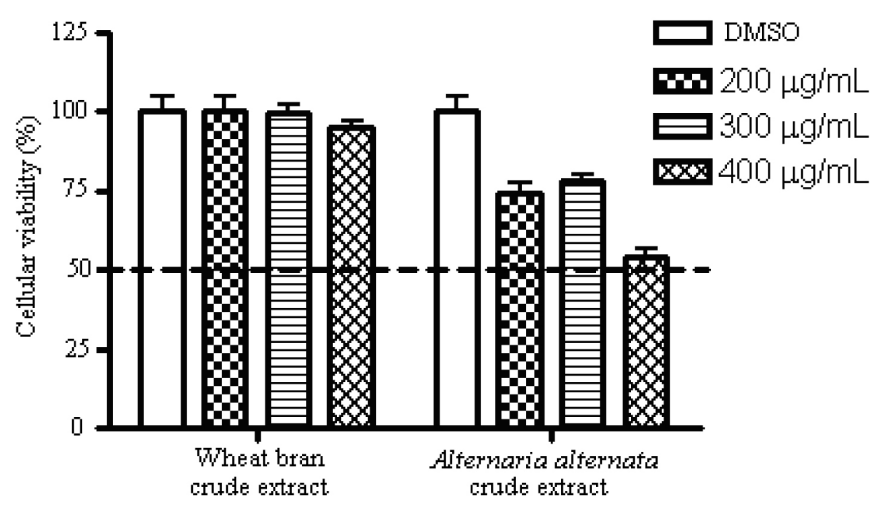

FIGURE 3 - Cytotoxic analysis of crude extract of wheat bran and Alternaria alternata on Hela cells. The data represent averages of three independent experiments performed in triplicate.

The cytotoxic assays showed moderate activity of the crude extract of Alternaria alternata on the viability of HeLa cells in vitro, when compared to the DMSO treated cells. Three concentrations were tested varying between $200-400 \mu \mathrm{g} / \mathrm{mL}$ and, it was determined that, in the concentration of $400 \mu \mathrm{g} / \mathrm{mL}$, the crude extract of the endophyte was able to inhibit about $50 \%$ of cell proliferation in $\mathrm{HeLa}$ cells. In this test, the crude extract of wheat bran showed no activity on the tested cells.

Several cytotoxic compounds have been isolated from endophytic fungi, showing the potential of these fungi in the search for antitumoral agents (Guimarães et al., 2008).

Liu et al. (2007) demonstrated for the first time that alternol, a new compound purified from the fermenting products of Alternaria alternata var. monosporus, from the bark of Yew, was found to inhibit proliferation and induce apoptosis in mouse lymphocyte leukemia L1210 cells. Alternol induced the activation of caspase- 3 and caspase-9, but not caspase-8. Moreover, there was a significant increase in the reactive oxygen species (ROS) which might also play a role in apoptosis. Based on this study, we can suggest that Alternaria alternata is able to produce this compound with cytotoxic activity for HeLa cells.

Firáková, Sturdíková and Múcková (2007) presented the overview of bioactive secondary metabolites with anticancer activity produced by endophytes, for example, camptothecin of a fungal endophytic isolate, podophyllotoxin, aryltetralignans of Trametes hirsuta, cytoskyrins of Curvularia lunata, macrolides of Streptomyces sp. Is9131 and brefeldine A of Phoma medicaginis, among others. 
Thus, endophytic fungi play an important role in the search for antitumoral compounds and might also represent an alternative source for the production of therapeutic agents that are not easily obtained by chemical synthesis. The potential of these fungi is of great interest and warrants further investigation.

\section{ACKNOWLEDGMENTS}

The authors would like to thank Unifal-MG and PROAP-Capes for financial support.

\section{REFERENCES}

AHN M.-R.; KUMAZAWA, S.; HAMASAKA, T.; BANG, K.S.; NAKAYAMA, T. Antioxidant activity and constituents of propolis collected in various areas of Korea. J. Agric. Food Chem., v.52, p.7286-7292, 2004.

ARNOLD, A. E.; ZULEYKA, M.; GILBERT, G. S.; COLEY, P. D.; KURSAR, T. A. Are tropical fungal endophytes hyperdiverse? Ecol. Lett., v.3, p.267-274, 2000.

CLINICALAND LABORATORY STANDARDS INSTITUTE. Performance standards for antimicrobial susceptibility testing: Fifteenth Informational Supplement CLSI document M100-S15. Wayne: CLSI, 2005. p.177.

DUARTE, S.; KOO, H.; BOWEN, W. H.; HAYACIBARA, M. F.; CURY, J. A.; IKEGAKI, M.; ROSALEN, P. L. Effect of a novel type of propolis and its chemical fractions on glucosyltransferases and on growth and adherence of mutans streptococci. Biol. Pharm. Bull., v.26, p.527-531, 2003.

FIRÁKOVÁ, S.; STURDÍKOVÁ, M.; MÚCKOVÁ, M. Bioactive secondary metabolites produced by microorganisms associated with plants. Biol. Bratislava, Section Botany, v.62, p.251-257, 2007.

GUANATILAKA, A. A. L. Natural products from plantassociated microorganisms: distribution, structural diversity, bioactivity, and implications of their occurrence. J. Nat. Prod., v.69, p.509-526, 2006.

GUIMARÃES, D. O.; BORGES, W. S.; KAWANO, C. Y.; RIBEIRO, P. H.; GOLDMAN, G. H.; NOMIZO, A.; THIEMANN, O. H.; OLIVA, G.; LOPES, N. P.; PUPO, M. $\mathrm{T}$. Biological activities from extracts of endophytic fungi isolated from Viguiera arenaria and Tithonia diversifolia. FEMS Immunol. Med. Microbiol., v.52, p.134-144, 2008.
GÜLÇIN, İ.; ALICI, H. A; CESUR, M. Determination of in vitro antioxidant and radical scavenging activities of propofol. Chem. Pharm. Bull., v.53, p.281-285, 2005.

HAWKSWORTH, D. L. The fungal dimension of biodiversity: magnitude, significance, and conservation. Mycol. Res., v.95, p.641-655, 1991.

HELLWIG, V.; GROTHE, T.; MAYER-BARTSCHMID, A.; ENDERMANN, R.; GESCHKE, F. U.; HENKEL, T.; STADLER, M. Altersin, a new antibiotic from cultures of endophytic Alternaria spp. taxonomy, fermentation, isolation, structure elucidation and biological activities. $J$. Antib., v.55, p.881-892, 2002.

HUANG, W.-Y.; CAI, Y.-Z.; XING, J.; CORKE, H.; SUN, M. A potential antioxidant resource: endophytic fungi from medicinal plants. Econ. Bot., v.61, p.14-30, 2007.

KOO, H.; GOMES, B. P. F. A.; ROSALEN, P. L.;AMBROSANO, G. M. B.; PARK, Y. K.; CURY, J. A. In vitro antimicrobial activity of propolis and Arnica Montana against oral pathogens. Arch. Oral Biol., v.45, p.141-148, 2000.

LI, Y.; SONG, Y. C.; LIU, J. Y.; MA, Y. M.; TAN, R. X. Antihelicobacter pylori substances from endophytic fangal cultures. World J. Microbiol. Biotechnol., v.21, p.553-558, 2005.

LIN, X.; LU, C.; HUANG, Y.; ZHENG, Z.; SU, W.; SHEN, Y. Endophytic fungi from a pharmaceutical plant, Camptotheca acuminate: isolation, identification and bioactivity. World $J$. Microbiol. Biotechnol., v.23, p.1037-1040, 2007.

LIU, X.; DONG, M.; CHEN, X.; JIAN, M., LV, X; YAN, G. Antioxidant activity and phenolics of an endophytic Xylaria sp. from Gingko biloba. Food Chem., v.105, p.548-554, 2007.

LIU, Z.-Z.; ZHU, J.; SUN, B.; LIU, S.; GENG, S.; LIU, X.; LI, C.-L. Alternol inhibits proliferation and induces apoptosis in mouse lymphocyte leukemia (L1210) cells. Mol. Cell. Biochem., v.306, p.115-122, 2007.

LORIAN, V. Antibiotics in laboratory medicine. 3ed. Baltimore: Williams and Wilkins, $1996.330 \mathrm{p}$.

MOSMANN, T. Rapid colorimetric assay for cellular growth and survival: application to proliferation and cytotoxicity assays. J. Immunol. Methods, v.65, p.55-63, 1983. 
NEWMAN, D. J.; CRAGG, G. M.; SNADER, K. M. Natural products as sources of new drugs over the period 19812002. J. Nat. Prod., v.66, p.1022-1037, 2003.

PETERSEN, P. J.; WANG, T. Z.; DUSHIN, R. G.; BRADFORD, P. A. Comparative in vitro activities of AC98-6446, a novel semisynthetic glycopeptide derivate of the natural product mannopeptimycin alpha and other antimicrobial agents against Gram-positive clinical isolates. Antim. Agents Chemother., v.48, p.739-746, 2004.

PETRINI, O.; SIEBER, T. N.; TOTI, L. VIRET, O. Ecology, metabolite production and substrate utilization in endophytic fungi. Nat. Toxins, v.1, p.185-196, 1992.

PETRINI, O.; STONE J.; CARROLL, F. E. Endophytic fungi in evergreen shrubs in wester Oregon: a preliminary study. Can. J. Botany, v.60, p.789-796, 1982.

P H O N G PA I C H I T, S .; R UN G J IN D A M A I, N . ; RUKACHAISIRIKUL, V.; SAKAYAROJ, J. Antimicrobial activity in cultures of endophytic fungi isolated from Garcinia species. FEMS Immunol. Med. Microbiol., v.48, p.367-372, 2006.

RÍOS, J. L.; RECIO, M. C. Medicinal plants and antimicrobial activity. J. Ethnopharmacol., v.100, p.80-84, 2005.

SANTAMARIA, J.; BAYMAN, P. Fungal epiphytes and endophytes of coffee leaves (Coffea arabica). Microbiol. Ecol., v.50, p.1-8, 2005.

SCHROEDER, H. W.; COLE, R. J. Natural occurrence of alternariols in discolored pecans. J. Agric. Food Chem., v.25, p.204-206, 1977.

SCHULZ, B.; BOYLE, C.; DRAEGER, S.; ROMMERT, A.-K.; KROHN, K. Endophytic fungi: a source of novel biologically active secondary metabolites. Mycol. Res., v.106, p.996-1004, 2002.

SETTE, L. D.; PASSARINI, M. R. Z.; DELARMELINA, C.; SALATI, F.; DUARTE, M. C. T. Molecular characterization and antimicrobial activity of endophytic fungi from coffee plants. World J. Microbiol. Biotechnol., v.22, p.1185-1195, 2006.
SHON, M. Y.; KIM, T. H.; SUNG, N. J. Antioxidants and free radical scavenging activity of Phellimus baumii (Phellimus of Hymenochaetoceae) extracts. Food Chem., v.82, p.593597, 2003.

SILVA, J. F. M.; SOUZA, M. C.; MATTA, S. R.; ANDRADE, M. R.; VIDAL, F. V. N. Correlation analysis between phenolic levels of Brazilian propolis extracts and their antimicrobial and antioxidant activities. Food Chem., v.99, p.431-435, 2006.

SOARES, S. E. Phenolic acids as antioxidants. Rev. Nutr., v.15, p.71-81, 2002.

TORTORA, G. J.; FUNKE, B. K.; CASE, C. L. Microbiologia. 8.ed. Porto Alegre: Artmed, 2005. cap.4, p.83-84.

WANG, F. W.; JIAO, R. H.; CHENG, A. B.; TAN, S. H.; SONG, Y. C. Antimicrobial potentials of endophytic fungi residing in Quercus variabilis and brefeldin A obtained from Cladosporium sp. World J. Microbiol. Biotechnol., v.23, p.79-83, 2007.

WOISKY, R. G.; SALATINO, A. Analysis of propolis: some parameters and procedures for chemical quality control. $J$. Apic. Res., v.37, p.99-105, 1998.

YANISHLIEVA-MASLAROVA, N. V. Inhibiting oxidation. In: POKORNY, J.; YANISHLIEVA, N.; GORDON, M. H. (Ed.). Antioxidants in food: practical applications. Cambridge: CRC Press, 2001. p.22-70.

YEN, W. J.; CHANG, L. W.; DUH, P. D. Antioxidant activity of peanut seed testa and its antioxidative component, ethyl protocatechuate. Food Sci. Technol., v.38, p.193-200, 2005.

Received for publication on $17^{\text {th }}$ July 2008 . Accepted for publication on $20^{\text {th }}$ January 2009. 
